\title{
Prejudice in Perceptions of Physicians?: The Influence of Race and Gender on Evaluations of Medical Errors
}

\author{
N. Derek Brown, B.A. ', Larry R. Martinez, Ph.D. ', and Michelle "Mikki" R. Hebl, Ph.D. ${ }^{2}$ \\ ${ }^{1}$ Department of Psychology, Portland State University, Portland, OR, USA; ${ }^{2}$ Rice University, Houston, TX, USA.
}

KEY WORDS: Physician race; Physician gender; Medical errors; Patient care.

J Gen Intern Med 33(6):807-8

DOI: $10.1007 / \mathrm{s} 11606-018-4385-\mathrm{y}$

(c) Society of General Internal Medicine 2018

\section{INTRODUCTION}

Little is known about prejudicial attitudes patients have toward physicians. Past research shows that physicians commonly face discrimination ${ }^{1-3}$, and although Asian physicians constitute the largest ethnic minority population of practicing physicians, ${ }^{4}$, there is no research that examines their experiences with discrimination explicitly. Asian professionals are subject to both positive and negative stereotypes, such that they are categorized as highachieving (e.g., intelligent, successful), yet also perpetually foreign and never accepted into the American milieu. ${ }^{5}$ This research examined how patient biases can influence evaluations of physicians as a function of physician race, gender, and severity of a medical error.

\section{METHOD}

We recruited 482 adults (59\% female) using Amazon's MTurk. ${ }^{6}$ Participants were randomly assigned to view one website and one incident report that we altered to manipulate physician ethnicity (White vs. Indian), gender (male vs. female), and medical error severity (major vs. minor error). We assessed participant evaluations of the physician with questions about patient care characteristics $(\alpha=.86)$ and the appropriateness of various consequences that could be "taken against the physician" $(\alpha=.89)$. We compared mean differences based on participant impressions as a function of error severity and physician ethnicity and gender (MANOVA) and assessed for potential relationships between physician demographic characteristic and suggested consequences using regression analysis (Hayes' PROCESS Macro Model 4). An a priori power analysis (with $\alpha=.05$ and power $=.95$ ) revealed an adequate sample size to detect differences in effect sizes as small as .025.

Published online March 12, 2018

\section{RESULTS}

The mean age of participants was $37.09(S D=12.54)$ and $77 \%$ of participants were White/Caucasian. Table 1 provides means, standard deviations, reliabilities, and correlations of the variables included in the analyses. There were no differences in care quality perception or suggested consequences for severe errors between race and gender groups (Table 2). For all groups, patient care perceptions were more negative and consequences for major errors were more severe compared to minor ones $(F(2,473)=$ $38.97, p<.001)$.

For minor errors, there was no difference between patient care perception or desired consequences for White or Indian men or Indian women. However, White women were viewed more positively in terms of their provision of patient care $\left(F(1,474)=4.77, p<.05, \eta^{2}=.01\right)$ compared to other physicians, evaluated as a group $(M=4.24$, $S D=1.08)$. Similarly, White women were treated more leniently in terms of suggested consequences $(F(1$, $\left.474)=4.52, p<.05, \eta^{2}=.01\right)$ compared to the other physicians $(M=2.94, S D=1.32)$. For major errors, there were no differences based on race or gender.

In our multivariable model, we found that the leniency for White female physicians could be explained by the perception that White women have greater ability to provide care following a minor error, $b=-0.19(S E=0.09), 95 \%$ CI $[-0.40,-$ 0.02].

\section{DISCUSSION}

Our results suggest that evaluations of physicians are not only linked to the severity of the error committed, but also to physician gender and race. Unexpectedly, we found that Indian physicians were rated no differently than White male physicians, despite having sufficient power to detect an effect. Results also revealed differential evaluations for White female physicians in comparison to White male, Indian male, and Indian female physicians, though only for minor errors. Specifically, White female physicians were rated as better caretakers and elicited the least severe sanctions (despite equivalent performance).

Our data suggest that physician race and gender may be instrumental in an individual's evaluation toward 
Table 1 Means, SD, Correlations, and Reliabilities of Study Variables $(N=482)$

\begin{tabular}{llllll}
\hline \hline Variables & M [SD] & Error severity & Gender & Race & Patient care \\
\hline 1. Error severity & $0.51[0.50]$ & - & & & \\
2. Physician gender & $0.47[0.50]$ & 0 & - & & \\
3. Physician race & $0.45[0.50]$ & -0.06 & -0.05 & - & $(0.86)$ \\
4. Patient care & $4.06[1.17]$ & $0.24^{*}$ & -0.06 & 0.01 & $-0.53^{*}$ \\
5. Consequences & $3.36[1.42]$ & $-0.37^{*}$ & 0.04 & -0.06 & $(0.89)$ \\
\hline
\end{tabular}

*Correlation is significant at $p<.01$. Cronbach's alpha reliabilities appear on the diagonal in parentheses

Table 2 Perceptions of Care Quality and Consequences by Race and Gender, M [SD]

\begin{tabular}{|c|c|c|c|c|c|}
\hline & & \multicolumn{2}{|c|}{ White } & \multicolumn{2}{|c|}{ Indian } \\
\hline & & Men & Women & Men & Women \\
\hline \multirow[t]{2}{*}{$\begin{array}{l}\text { Severe } \\
\text { error }\end{array}$} & Care & $\begin{array}{l}3.58 \\
{[1.07]}\end{array}$ & $\begin{array}{l}3.84 \\
{[1.25]}\end{array}$ & $\begin{array}{l}3.86 \\
{[1.26]}\end{array}$ & $\begin{array}{l}3.80 \\
{[1.12]}\end{array}$ \\
\hline & Consequences & $\begin{array}{l}3.86 \\
{[1.10]}\end{array}$ & $\begin{array}{l}3.78 \\
{[1.36]}\end{array}$ & $\begin{array}{l}4.07 \\
{[1.46]}\end{array}$ & $\begin{array}{l}3.89 \\
{[1.45]}\end{array}$ \\
\hline \multirow[t]{2}{*}{$\begin{array}{l}\text { Minor } \\
\text { error }\end{array}$} & Care & $\begin{array}{l}4.23 \\
{[1.13]}\end{array}$ & $\begin{array}{l}4.61 \\
{[1.17]}\end{array}$ & $\begin{array}{l}4.24 \\
{[1.05]}\end{array}$ & $\begin{array}{l}4.24 \\
{[1.05]}\end{array}$ \\
\hline & Consequences & $\begin{array}{l}2.89 \\
{[1.53]}\end{array}$ & $\begin{array}{l}2.53 \\
{[1.18]}\end{array}$ & $\begin{array}{l}2.91 \\
{[1.27]}\end{array}$ & $\begin{array}{l}3.03 \\
{[1.17]}\end{array}$ \\
\hline
\end{tabular}

physicians, above and beyond what may be deserved based on their performance alone. Thus, our results highlight the pernicious effects of racial and gender stereotypes in the doctor-patient relationship, which can translate to largescale consequences (e.g., pursuing malpractice lawsuits). ${ }^{7}$ This research reveals that in order to manage equitable hospital climates, in which being female or being nonWhite does not yield career disadvantage, research must continue understanding biases of patients and physicians that hinder effective medical care.

Acknowledgments: The authors thank Abigail Corrington, Christine Nittrouer-Carr, Rachel Trump-Steele, and Nicholas Smith for their help coordinating this project, recruiting participants, analyzing data, and providing feedback. Additionally, the authors thank the individuals who agreed to participate in this study as confederates. An earlier version of this study was presented at the Society of Industrial and Organizational Psychology Conference in Orlando, FL in April 2017.

Corresponding Author: Larry R. Martinez, Ph.D.; Department of Psychology Portland State University, Portland, OR, USA (e-mail: larry. martinez@pdx.edu).

\section{Compliance with Ethical Standards:}

Conflicts of Interest: The authors declare that they do not have a conflict of interest.

\section{REFERENCES}

1. Nunez-Smith M, Pilgrim N, Wynia M, et al. Race/ethnicity and workplace discrimination: results of a national survey of physicians. J Gen Intern Med. 2009;24:1198-1204.

2. Chen PW. When the patient is racist [Internet]. New York: The New York Times. 2013 July 25 [cited 2018 Feb 1]. Available from: https://well.blogs. nytimes.com/2013/07/25/when-the-patient-is-racist/

3. Novick DR. Racist patients often leave doctors at a loss [Internet]. Washington DC: The Washington Post; 2017 Oct 19 [cited 2018 Feb 1]. Available from: https://www.washingtonpost.com/opinions/racist-patients-often-leave-doctors-at-a-loss/2017/10/19/9e9a2c46-9d55-11e79c8d-cf053ff30921_story.html?utm_term=.0697479f9746

4. U.S. physicians by race, ethnicity, and sex, 2013. [dataset on the Internet]. 2014. Washington, DC: Association of American Medical Colleges; 2014 [cited 2018 Feb 1]. Available from http://aamcdiversityfactsandfigures. org/section-ii-current-status-of-us-physician-workforce/

5. Lee SJ, Wong NWA, Alvarez AN. The model minority and the perpetual foreigner: stereotypes of Asian Americans. In: Tewari N, Alvarez AN, editors. Asian American psychology. New York: Routledge/Taylor \& Francis Group; 2009. p. 69-84.

6. Feitosa J, Joseph DL, Newman DA. Crowdsourcing and personality measurement equivalence: a warning about countries whose primary language is not English. Pers Individ Diff. 2015;75:47-52.

7. O'Toole TM, Boyd BA, Prosise TO. The anatomy of a medical malpractice verdict. Mont. L. Rev. 2009; 70:57-91. 